Ekspansi: Jurnal Ekonomi, Keuangan, Perbankan dan Akuntansi

ISSN (Online): 2580-7668 ISSN (Print): 2085-5230

Vol. 11, No. 1 (Mei 2019), Hal. 87 - 100

\title{
KONDISI MAKROEKONOMI SEBAGAI FAKTOR YANG MEMPENGARUHI NERACA TRANSAKSI BERJALAN PERIODE 1999 - 2016
}

\author{
Erric Wijaya ${ }^{1}$ \\ ${ }^{1}$ Indonesia Banking School, Jakarta, Indonesia \\ Email Korespondensi: erric.wijaya@ibs.ac.id
}

\begin{abstract}
This study discusses the current account and itsinfluencing factors. The factors influencing the current account are macroeconomic factors, including national income (GDP), inflation, interest rate (SBI), and exchange rate. The period of this study starts from 1999 - 2016 using annual data. This study looks at the short-term and long-term effects of macroeconomic factors that affect the current account balance. The research model of this study was using cointegration test and Error Correction Model (ECM). The results showed that in the long run, the macroeconomic variables of national income (GDP) and inflation significantly influenced the current account balance. While in the short term, macroeconomic variables inflation and exchange rate significantly influenced the current account balance. Thus it can be concluded that, the inflation variable is the main macroeconomic variable that influenced the current account balance in the long term and in the short term.
\end{abstract}

Keywords: Current Account, National Income, SBI Interest, Inflation, Exchange Rate

Abstrak: Penelitian ini membahas mengenai neraca transaksi berjalan dan faktor-faktor yang mempengaruhinya. Adapun faktor yang mempengaruhi neraca transaksi berjalan adalah faktor makroekonomi, yaitu pendapatan nasional (GDP), inflasi, tingkat bunga (SBI), dan nilai tukar. Periode penelitian dimulai dari tahun 1999 - 2016 dengan menggunakan data tahunan. Penelitian ini melihat pengaruh jangka pendek dan jangka panjang factor makroekonomi yang mempengaruhi neraca transaksi berjalan. Adapun model penelitian ini menggunakan metode uji kointegrasi dan Error Correction Model (ECM). Hasil penelitian menunjukkan bahwa pada jangka panjang, variabel makroekonomi pendapatan nasional (GDP) dan inflasi berpengaruh signifikan terhadap neraca transaksi berjalan. Sedangkan pada jangka pendek, variabel makroekonomi inflasi dan nilai tukar berpengaruh signifikan terhadap neraca transaksi berjalan. Sehingga dapat disimpulkan bahwa, variabel inflasi merupakan variabel utama makroekonomi yang mempengaruhi neraca transaksi berjalan baik pada jangka panjang maupun pada jangka pendek.

Kata Kunci: Neraca Transaksi Berjalan, Pendapatan Nasional, Tingkat Bunga SBI, Inflasi, Nilai Tukar

DOI: $10.35313 /$ ekspansi.v11i1.1247

Riwayat Artikel:

Diterima: 25 - 1 - 2019

Direvisi: 8 - 4 - 2019

Disetujui: 14 - 4-2019 


\section{PENDAHULUAN}

Dewasa ini Globalisasi merupakan hal yang mutlak dilakukan oleh setiap negara. Globalisasi adalah proses integrasi internasional yang terjadi karena pertukaran pandangan dunia, produk, pemikiran, dan aspek-aspek kebudayaan lainnya. Terdapat beberapa faktor yang menyebabkan fenomena globalisasi mutlak dilakukan, antara lain: 1. Kemajuan ilmu pengetahuan dan teknoplogi; 2. Diterapkannya perdagangan bebas; 3. Liberalisasi keuangan internasional; dan 4. Meningkatnya hubungan antar negara. Adapun tujuan dari adanya globalisasi adalah:1. Mempercepat penyebaran informasi, 2. Mempermudah setiap orang untuk memenuhi kebutuhan hidup; dan 3. Memberikan kenyamanan dalam aktivitas.

Salah satu bagian dari globalisasi adalah perekonomian terbuka (open economic) dimana setiap negara dapat melakukan interaksi perekonomian secara bebas dengan perekonomian dinegara lainnya. Menurut mankiw (2014), terdapat dua cara untuk melakukan interaksi tersebut, yaitu melalui pembelian dan penjualan surat berharga (capital flow) dan melalui pembelian dan penjualan barang dan jasa (ekspor-impor).

Pada penelitian ini membatasi salah satu dampak dari perekonomian terbuka yaitu melalui pembelian dan penjualan barang dan jasa. Secara garis besar, transaksi penduduk Indonesia dengan penduduk negara lain dapat dilihat pada neraca pembayaran. Neraca Pembayaran Indonesia (NPI) merupakan statistik yang mencatat transaksi ekonomi antara penduduk Indonesia dengan bukan penduduk pada suatu periode tertentu (BI, 2009). Adapun neraca pembayaran terdiri dari:

a. Transaksi Berjalan. Transaksi berjalan mengukur penerimaan dan pengeluaran Indonesia yang berasal dari transaksi barang dan jasa, pendapatan, dan transfer berjalan dengan bukan penduduk. Transaksi dalam transaksi berjalan bersifat final, dalam arti transaksi tersebut tidak dihubungkan dengan transaksi sebelumnya atau yang akan datang, sebagaimana umumnya transaksi finansial, misalnya penyelesaian atas tagihan finansial atau timbulnya pendapatan investasi.

b. Transaksi Modal dan Finansial. Transaksi modal mencakup transfer modal dan transaksi terkait aset nonfinansial tidak terbarukan (non-produced, non-financial assets). Transfer modal berisikan transfer kepemilikan atas aset tetap tanpa imbalan secara langsung, atau transfer dana yang terkait dengan aset tetap, atau pembatalan klaim finansial dengan kesepakatan bersama antara kreditur dan debitur (pengampunan utang-debt forgiveness).

Adapun perkembangan neraca pembayaran Indoenesia dapat dilihat pada Tabel 1 berikut ini.

Tabel 1. Neraca Pembayaran (Juta USD)

\begin{tabular}{|c|c|c|c|c|c|c|c|}
\hline & Keterangan & 2011 & 2012 & 2013 & 2014 & 2015 & 2016 \\
\hline & Transaksi & 1685.08 & 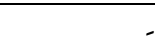 & & & & \\
\hline & berjalan & 32.89 & 24418.12 & 29109.46 & 27509.87 & 17518.74 & 16346.92 \\
\hline II. & Transaksi Modal & 13603.33 & 50.57 & 45.29 & 26.57 & 16.63 & 9.49 \\
\hline \multirow{2}{*}{ III. } & Transaksi & 15321.3 & 24858.06 & 21925.58 & 44916.08 & 16843.1 & 29188.09 \\
\hline & Financial & -3464.68 & 490.5 & -7138.58 & 17432.79 & -659.01 & 12850.66 \\
\hline \multirow{2}{*}{\multicolumn{2}{|c|}{ IV. Total }} & 11856.6 & -275.38 & -186.15 & -2184.2 & -439.04 & -761.79 \\
\hline & & & 215.12 & -7324.73 & 15248.59 & -1098.05 & 12088.87 \\
\hline
\end{tabular}




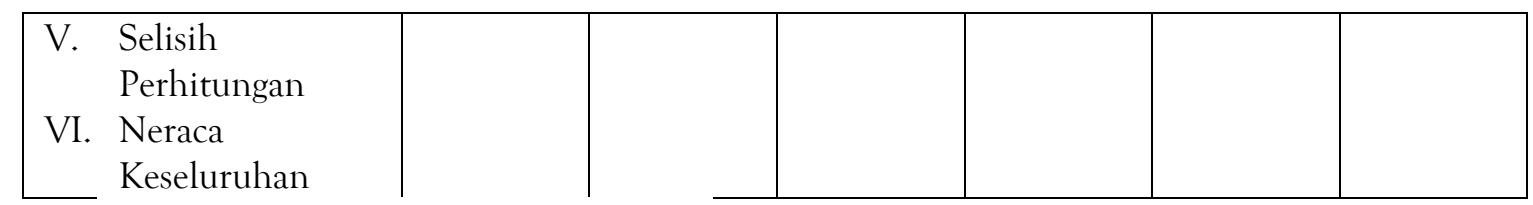

Sumber: SEKI Bank Indonesia, 2017.

Pada Tabel 1. terlihat bahwa secara keseluruhan neraca pembayaran menunjukkan nilai bervariasi. Diantara tahun 2011-2016, terdapat dua tahun, yaitu tahun 2013 dan 2015 neraca pembayaran menunjukkan nilai yang defisit. Sedangkan selebihnya menunjukkan nilai surplus. Khusus tahun 2016 neraca pembayaran Indonesia mencapai surplus sebesar \$12088.87 juta. Surplus neraca pembayaran tahun 2016 disebabkan peningkatan pada transaksi financial sebesar \$29188.09 terbesar diantara tahun 2011 - 2016.

Banyak faktor yang mempengaruhi neraca transaksi berjalan, salah satunya adalah faktor makroekonomi. Semakin baik dan stabil kondisi makroekonomi maka diharapkan neraca transaksi berjalan akan semakin surplus yang juga pada akhirnya akan mempengaruhi neraca pembayaran suatu negara. Faktor makroekonomi yang akan digunakan adalah pendapatan nasional, nilai tukar, inflasi, dan tingkat suku bunga.

Variabel pendapatan nasional di proxy dengan GDP. Menurut Samuelson (2009), PDB adalah jumlah output total yang dihasilkan dalam batas wilayah suatu negara dalam satu tahun. PDB mengukur nilai barang dan jasa yang diproduksi di wilayah suatu negara tanpa membedakan kewarganegaraan pada suatu periode waktu tertentu. Sukirno (2016), mendefinisikan PDB sebagai nilai barang dan jasa dalam suatu negara yang diproduksi oleh faktor-faktor produksi milik warga negara tersebut dan warga negara asing. Hasil penelitian yang dilakukan oleh Calderon et,al, Ukhrowiyah menyatakan bahwa pendapatan nasional berpengaruh positif terhadap neraca transaksi berjalan.

Variabel berikutnya yang diduga mempengaruhi neraca transaksi berjalan adalah nilai tukar. Nilai tukar mencerminkan harga mata uang suatu negara dibandingkan dengan mata uang negara lainnya. Hasil penelitian yang dilakukan oleh Calderon et al menunjukkan apresiasi nilai tukar suatu negara menyebabkan memperburuk neraca pembayaran yang berakibat pada semakin meningkatnya defisit neraca transaksi berjalan, sedangkan penelitian yang dilakukan oleh Ukhrowiyah menunjukkan tidak terdapat pengaruh yang signifikan baik pada jangka pendek maupun jangka panjang terhadap defisit neraca transaksi berjalan.

Variabel makroekonomi berikutnya adalah inflasi. Inflasi mengukur rata-rata kenaikan tingkat harga barang dan jasa selama periode waktu tertentu. Menurut Mankiw (2015), terdapat tiga metode perhitungan inflasi, yaitu:

\section{a. Indeks harga konsumen (IHK)}

yaitu menghitung biaya keseluruhan barang dan jasa yang di konsumsi oleh setiap konsumen. Menurut BPS, IHK merupakan suatu indeks yang menghitung rata-rata perubahan harga dalam suatu periode, dari suatu kumpulan barang dan jasa yang dikonsumsi oleh penduduk/rumah tangga dalam kurun waktu tertentu. 
Maka didapatkan rumus perhitungan inflasi, adalah:

$$
\llbracket I n f l a s i \rrbracket_{-} t=\left(\llbracket I H K \rrbracket_{-} t-\llbracket I H K \rrbracket_{-}(t-1)\right) / \llbracket I H K \rrbracket_{-}(t-1) x 100 \%
$$

b. Indeks Harga produsen (IHP)

Yaitu menghitung biaya barang dan jasa yang dikonsumsi oleh perusahaan. Di Indonesia perhitungan IHK dikenal dengan Indeks Harga Perdagangan Besar (IHPB). Menurut BPS, Harga perdagangan besar dari suatu komoditas ialah harga transaksi yang terjadi antara penjual/pedagang besar pertama dengan pembeli/pedagang besar berikutnya dalam jumlah besar pada pasar pertama atas suatu komoditas.

(1) Pedagang besar pertama ialah pedagang besar sesudah produsen/penghasil

(2) Pasar pertama ialah tempat bertemunya antara pedagang besar pertama dengan pedagang berikutnya (bukan konsumen), dengan kata lain yaitu pasar sesudah pasar produsen

(3) Jumlah besar atau grosir artinya tidak atau bukan eceran.

\section{c. GDP deflator}

Merupakan salah satu alat pengukuran inflasi GDP deflator merupakan rasio GDP nominal terhadap GDP riil. Karena GDP nominal adalah nilai output saat ini dengan harga saat ini dan GDP riil adalah tingkat output saat ini dengan tingkat harga tahun dasar, sehingga GDP deflator merefleksikan tingkat harga saat ini relatif terhadap tingkat harga pada tahun dasar. Adapun rumus GDP deflator adalah:

\section{【GDP Deflator $\rrbracket_{-} t=\llbracket$ Nominal GDP $\rrbracket \_t /($ real GDP $) x 100$}

Hasil penelitian yang dilakukan oleh Cesar R Sobrino menyatakan bahwa inflasi menyebabkan memburuknya neraca transaksi berjalan.

Tingkat bunga merupakan variabel makroekonomi terakhir yang diduga mempengaruhi neraca transaksi berjalan. Tingkat bunga adalah ukuran investasi yang dapat diperoleh investor dan juga ukuran biaya modal yang harus dikeluarkan oleh perusahaan untuk menggunakan dana dari investor. Secara umum, tingkat bunga dibagi menjadi dua jenis, yaitu:

a. Tingkat bunga nominal. Merupakan tingkat bunga yang tidak memasukkan unsur/dampak inflasi dan tingkat bunga ini langsung dipublikasikan oleh pihak perbankan/

b. Tingkat bunga riil. Merupakan tingkat bunga yang sudah dikoreksi dengan inflasi. Tingkat bunga ini mencerminkan pendapatan oleh penabung yang sudah menghilangkan dampak perubahan harga. Adapun rumus tingkat bunga riil adalah:

$$
\text { Tingkat bunga riil = tingkat bunga nominal }- \text { inflasi }
$$

Tingkat bunga SBI merupakan benchmark bagi investor untuk membandingkan investor dalam bidang lainnya. Markus,et al dan Calderon et, al menyatakan bahwa penurunan tingkat bunga menyebabkan meningkatnya defisit neraca transaksi berjalan. 


\section{METODE PENELITIAN}

Penelitian ini ingin menganalisis Kondisi Makroekonomi Sebagai Faktor yang Mempengaruhi Neraca Transaksi Berjalan Periode 1999-2016. Data yang digunakan adalah data tahunan. Adapun variabel makroekonomi meliputi: pendapatan nasional, nilai tukar, inflasi, dan tingkat bunga.

Dalam penelitian ini digunakan jenis penelitian hypothesis testing yaitu penelitian yang dilakukan untuk menguji pengaruh antar variabel berdasarkan hipotesa yang dibuat. Metode yang digunakan dalam penelitian ini adalah suatu metode yang dalam menilai suatu objek penelitian yang berkenaan dengan suatu kondisi ataupun suatu fase tertentu, dengan cara menganalisis dan menginterpretasikan data-data dan informasi yang diperoleh dalam upaya membuat tesis atau gambaran secara sistematis, faktual dan akurat mengenai fakta-fakta atau sifat-sifat serta hubungan antar variabel yang diteliti. Data yang telah terkumpul kemudian diolah dan disajikan ke dalam bentuk tabel dalam upaya mempermudah proses analisis dan pengolahannya yang dibuat secara kuantitatif.

Jenis data yang diperlukan dalam penelitian ini adalah data sekunder. Data sekunder yang digunakan antara lain Statistik Ekonomi Keuangan Indonesia (SEKI), Laporan Tahunan Bank Indonesia, dan Laporan Badan Pusat Statistik, serta laporan dari Departemen Keuangan.

Pengaruh variabel-variabel makroekonomi terhadap neraca transaksi berjalan dapat dilihat pada gambar 1 berikut ini.

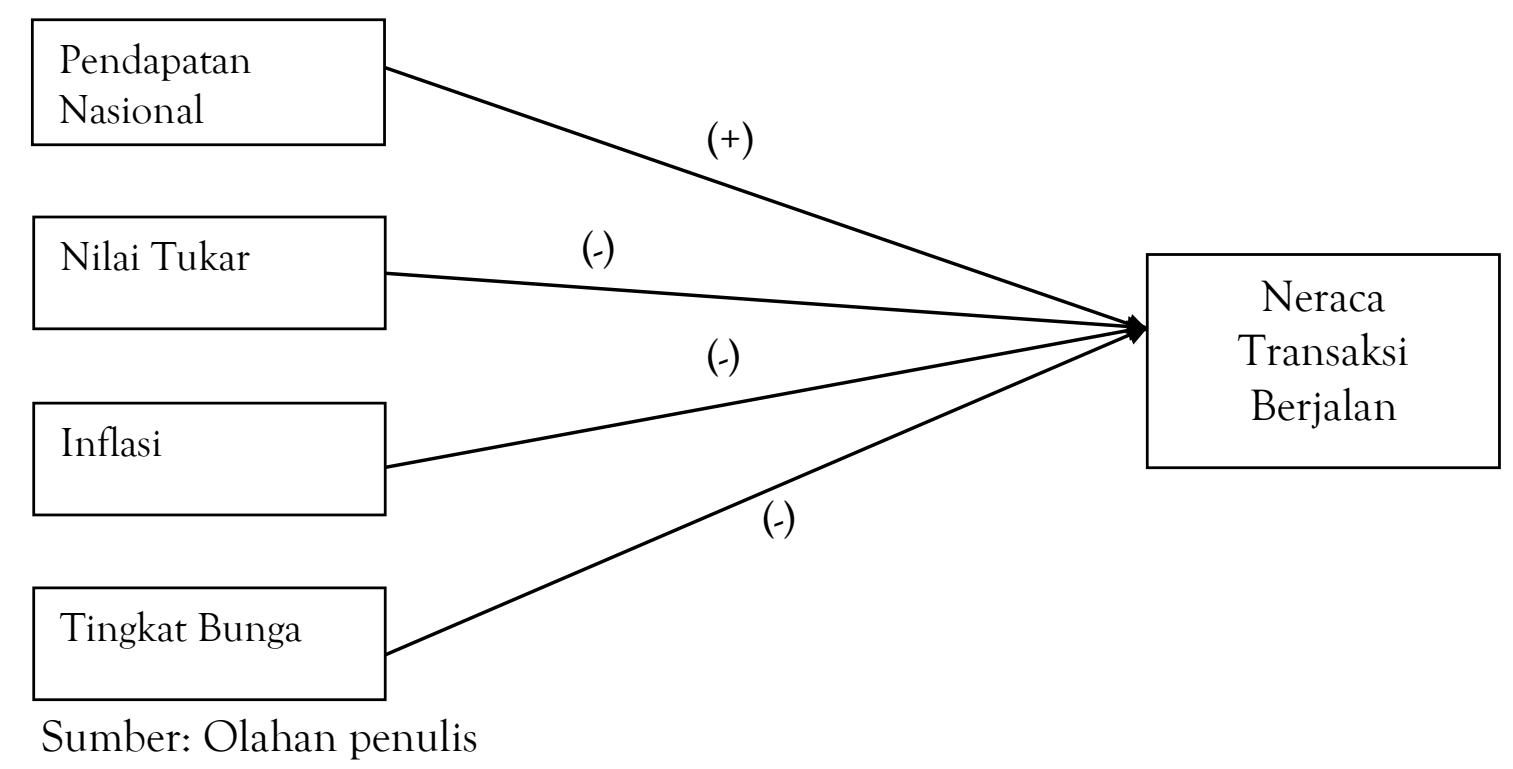

\section{Gambar 1. Rerangka Penelitian}

\section{Definisi Operasional}

Adapun variabel yang digunakan dalam penelitian ini dapat dilihat pada Tabel 2. 
Tabel 2. Variabel Operasional

\begin{tabular}{|l|l|l|l|l|}
\hline No & \multicolumn{1}{|c|}{ Variabel } & \multicolumn{1}{|c|}{ Konsep variabel } & \multicolumn{1}{|c|}{ Ukuran } & Skala \\
\hline 1 & $\begin{array}{l}\text { Neraca transaksi } \\
\text { berjalan }\end{array}$ & $\begin{array}{l}\text { Catatan sistematis } \\
\text { transaksi antar penduduk }\end{array}$ & $\begin{array}{l}\text { Nilai transaksi berjalan dalam } \\
\text { juta \$ per tahun }\end{array}$ & Rasio \\
\hline 2 & $\begin{array}{l}\text { Pendapatan } \\
\text { nasional }\end{array}$ & $\begin{array}{l}\text { Nilai seluruh barang dan } \\
\text { jasa yang dihasilkan dalam } \\
\text { suatu perekonomian } \\
\text { dengan proxy GDP }\end{array}$ & $\begin{array}{l}\text { Nilai GDP pengeluaran } \\
\text { menurut harga berlaku per } \\
\text { tahun }\end{array}$ & Rasio \\
\hline 3 & Nilai tukar & $\begin{array}{l}\text { Harga suatu mata uang } \\
\text { dengan mata uang negara } \\
\text { lain }\end{array}$ & $\begin{array}{l}\text { Diukur dari mata uang } \\
\text { rupiah terhadap dollar } \\
\text { Rp/USD yang diukur dari } \\
\text { rata-rata harian per tahun }\end{array}$ & Rasio \\
\hline 4 & Inflasi & $\begin{array}{l}\text { Rata-rata kenaikan harga } \\
\text { barang dan jasa dalam } \\
\text { periode tertentu }\end{array}$ & $\begin{array}{l}\text { Dihitung } \\
\text { menggunakan metode Indeks } \\
\text { Harga Konsumen (IHK) per } \\
\text { bulan dan diakumulasikan } \\
\text { selama setahun }\end{array}$ & Rasio \\
\hline 5 & Tingkat bunga & $\begin{array}{l}\text { Harga dari penggunaan } \\
\text { uang jangka waktu } \\
\text { tertentu }\end{array}$ & $\begin{array}{l}\text { Tingkat bunga diukur dari } \\
\text { tingkat bunga SBI per tahun }\end{array}$ & Rasio \\
\hline
\end{tabular}

Sumber: Olahan Penulis

\section{Model Penelitian}

Model Jangka Panjang Kointegrasi:

$$
N T B t^{*}=\beta 0+\beta 1 \text { Interest }_{t}+\beta 2 \text { Inflasi } i_{t}+\beta 3 G D P t+\beta 4 \text { Exchrate }_{t}+U t
$$

Keterangan

$\begin{array}{ll}\text { NTB } & =\text { Neraca Transaksi Berjalan } \\ \text { Interest } & =\text { Tingkat Suku Bunga } \\ \text { Inflasi } & =\text { Inflasi } \\ \text { GDP } & =\text { Tingkat Pendapatan Nasional } \\ \text { Exchrate } & =\text { Nilai tukar rupiah terhadap dolar } \\ \beta 0 & =\text { konstanta } \\ \mathrm{Ut} & =\text { nilai residual } \\ \beta_{1} \beta_{2} \beta_{3} \beta_{4} & =\text { pengaruh jangka panjang }\end{array}$

Model Jangka Pendek Error Correction Model dNTB $_{t}=\beta_{0}+\beta_{1} \sum_{i=0}^{n}$ dInterest $_{t}+\beta_{2} \sum_{i=0}^{n}$ dinflasi $_{t}+\beta_{3} \sum_{i=0}^{n} d G D P_{t}+\beta_{4} \sum_{i=0}^{n}$ dExchrate $_{t}+\beta_{5} E C T(-1)+\varepsilon_{t}$

Keterangan

ECT (-1) = Error Correction Term

\section{HASIL DAN PEMBAHASAN}

\subsection{Gambaran Umum Objek Penelitian}

Berikut kondisi neraca pembayaran Indonesia dari tahun 1999 - 2016 pada Gambar 2. 
Gambar 2. Neraca Pembayaran Indonesia (Juta \$)

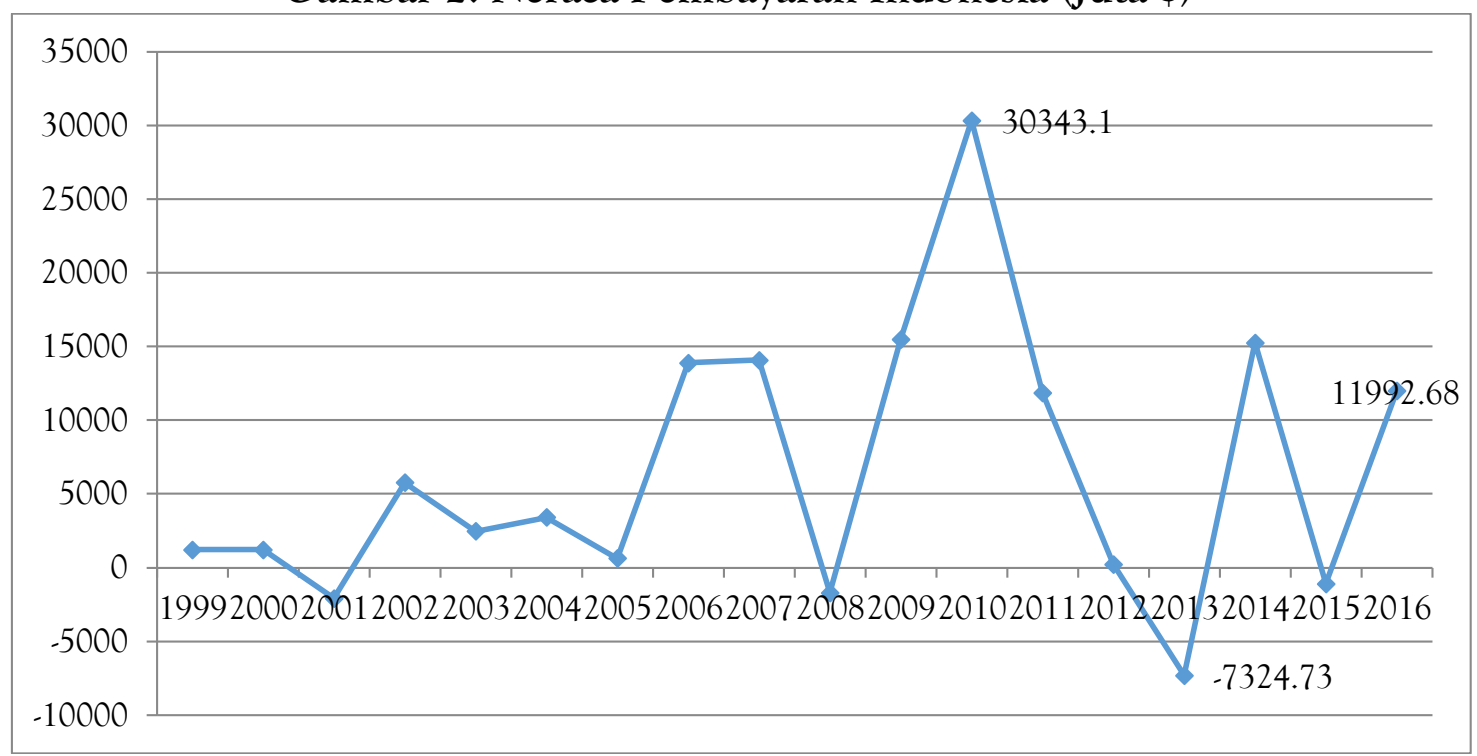

Sumber: olahan penulis

Berdasarkan Gambar 2. neraca pembayaran selama periode 1999 - 2016 mengalami fluktuasi. Hal ini tidak lain karena neraca pembayaran tidak hanya tergantung pada kondisi perekonomian didalam negeri tetapi juga sangat tergantung pada kondisi perekonomian di luar negeri. Indonesia pernah mengalami surplus neraca pembayaran tertinggi, yaitu pada tahun 2010 sebesar $\$ 30343.1$ juta. Hal ini disebabkan oleh tingginya pertumbuhan ekspor komoditas non migas, khususnya yang berbasis sumber daya alam, seiring kuatnya permintaan dunia dan tingginya harga di pasar internasional. Indonesia juga pernah mengalami deficit neraca pembayaran tertinggi selama periode 1999-2016, yaitu pada tahun 2013 sebesar $-\$ 7324.73$ juta. Menurut Bank Indonesia, defisit ini dipengaruhi melambatnya pertumbuhan ekonomi dunia dan turunnya harga komoditas global, yang kemudian berdampak pada penurunan ekspor Indonesia yang banyak berbasis sumber daya alam. Defisit transaksi berjalan juga dipengaruhi belum kuatnya kapasitas produksi domestik dalam memenuhi kebutuhan bahan baku dan barang modal serta kebijakan energi nasional yang belum optimal, yang pada gilirannya mendorong masih besarnya impor. Selain itu, Penurunan transaksi modal finansial terutama terjadi pada triwulan II dan triwulan III 2013 selain dipengaruhi turunnya modal masuk ke Indonesia yang dipicu oleh meningkatnya ketidakpastian di pasar keuangan global terkait rencana pengurangan stimulus moneter AS (tapering off) juga dipengaruhi persepsi negatif investor asing terhadap inflasi yang sempat meningkat dan defisit transaksi berjalan yang melebar.

Terakhir, pada tahun 2016, neraca pembayaran mengalami surplus sebesar \$11992.68 juta. Hal ini terjadi karena tingginya surplus neraca perdagangan diikuti rendahnya deficit neraca transaksi berjalan. Selain itu surplus juga ditopang oleh surplus pada neraca modal sehingga secara akumulasi menyebabkan neraca pembayaran tahun 2016 mengalami surplus. 
Neraca transaksi berjalan merupakan alat ukur untuk melihat posisi perdagangan baik barang maupun jasa Indonesia dengan negara lain. Perkembangan neraca transaksi berjalan Indonesia selama periode 1999 - 2016 dapat dilihat pada Gambar 3.

Gambar 3. Neraca Transaksi Berjalan (Juta \$)

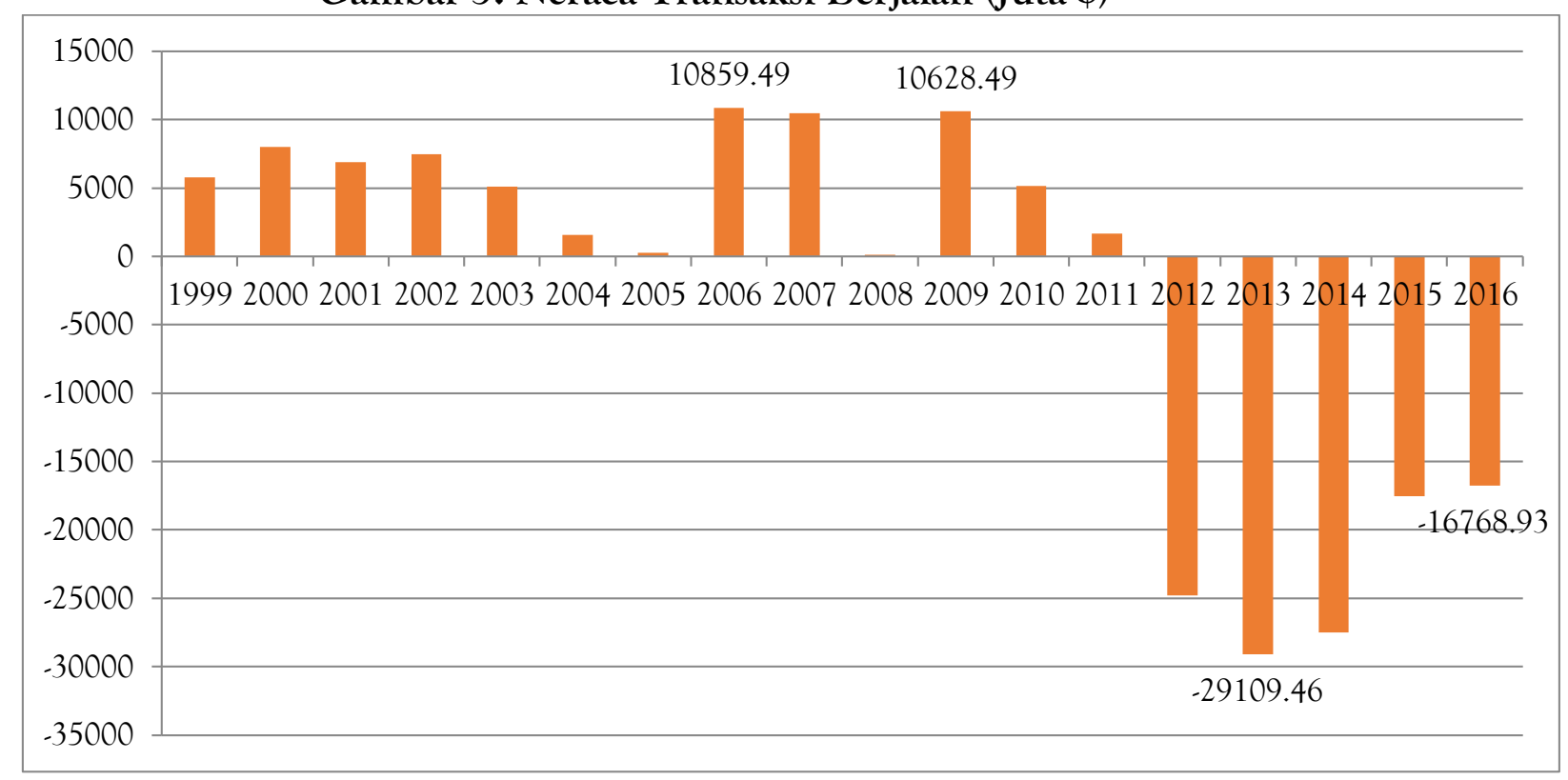

Sumber: Olahan penulis

Selama tahun 1999-2016, Indonesia pernah mengalami defisit tertinggi yaitu pada tahun 2013 sebesar $\mathbf{\$ 2 9 1 0 9 . 4 6}$ juta. Defisit ini dipengaruhi melambatnya pertumbuhan ekonomi dunia dan turunnya harga komoditas global, yang kemudian berdampak pada penurunan ekspor Indonesia yang banyak berbasis sumber daya alam. Indonesia juga pernah mengalami surplus transaksi berjalan tertinggi, yaitu tahun 2006 sebesar \$10859.49 juta. Hal ini di karenakan oleh perkembangan ekonomi global selama 2006 yang kondusif, khususnya tercermin pada kenaikan permintaan dunia dan harga komoditas, cukup besar pengaruhnya terhadap peningkatan ekspor Indonesia. Sebagai respons terhadap perkembangan ekonomi global tersebut, volume ekspor pada sebagian besar komoditas juga mengalami peningkatan. Terakhir pada tahun 2016, Indonesia mengalami defisit transaksi berjalan sebesar $-\$ 16768$.93. deficit ini terjadi karena defisit neraca perdagangan dimana transaksi ekspor lebih rendah dibandingkan transaksi impor selama tahun tersebut.

\subsection{Analisa Hasil}

\section{Pengujian Stasioneritas}

Pengujian stasioneritas merupakan pengujian untuk data yang bentuknya time series. Stasioneritas berarti bahwa tidak terdapat perubahan yang drastis pada data. Fluktuasi data berada di sekitar suatu nilai rata-rata yang konstan, tidak tergantung pada waktu dan variansi dari fluktuasi tersebut. Sekumpulan data dinyatakan stasioner jika nilai rata-rata dan varians dari data time series tersebut tidak mengalami perubahan 
secara sistematik sepanjang waktu atau dengan kata lain rata-rata dan variansnya konstan. Adapun hipotesa penelitian adalah sebagai berikut.

Ho: $\rho=0$, (terdapat unit root, artinya data tidak stasioner)

Ha: $\rho \neq 0$, (tidak terdapat unit root, artinya data stasioner)

Adapun hasil pengujian stasioner dapat dilihat pada Tabel 4.

Tabel 4. Hasil Pengujian Stasioner Pada Tingkat Level

\begin{tabular}{|l|l|l|l|}
\hline No & Variabel & Unit Root Test & Kesimpulan \\
\hline 1 & NTB & $0.6941^{* * *}$ & Tidak stasioner \\
\hline 2 & EXCHRATE & $0.7200^{* * *}$ & Tidak stasioner \\
\hline 3 & GDP & $0.8124^{* * *}$ & Tidak stasioner \\
\hline 4 & INFLASI & $0.2936^{* * *}$ & Tidak stasioner \\
\hline 5 & INTEREST & $0.1098^{* * *}$ & Tidak stasioner \\
\cline { 2 - 4 }
\end{tabular}

Ket: ${ }^{*} 1 \%,{ }^{* *} 5 \%,{ }^{* * *} 10 \%$

Berdasarkan pengujian stasioner semua variabel penelitian yaitu Neraca Transaksi Berjalan (NTB), nilai tukar (EXCHRATE), tingkat inflasi (INFLASI), tingkat bunga (INTEREST), dan pendapatan nasional (GDP) tidak stasioner pada tingkat level. Untuk itu maka dilakukan pengujian pada tingkat derajat 1. Adapun hasilnya dapat dilihat pada Tabel 5 .

Tabel 5. Hasil Pengujian Stasioner pada Derajat 1

\begin{tabular}{|l|l|l|l|}
\hline No & Variabel & Unit Root Test & Kesimpulan \\
\hline 1 & DNTB & $0.0167^{* *}$ & Stasioner \\
\hline 2 & DBOP & $0.0120^{* *}$ & Stasioner \\
\hline 3 & DGDP & $0.0864^{* * *}$ & Stasioner \\
\hline 4 & DINFLASI & $0.0003^{*}$ & Stasioner \\
\hline 5 & DINTEREST & $0.0021^{*}$ & Stasioner \\
\cline { 2 - 3 }
\end{tabular}

Ket: * $1 \%, * * 5 \%, * * * 10 \%$

Berdasarkan hasil pengujian stasioner pada derajat 1 pada Tabel 4.2, menunjukkan bahwa semua variabel bersifat stasioner pada tingkat derajat satu (I(1)). Hal ini dapat dianalisis dengan melihat nilai prob yang lebih rendah dari tingkat signifikansi $1 \%$ atau $5 \%$ atau $10 \%$. Sehingga dapat disimpulkan bahwa semua variabel yang digunakan dalam penelitian ini terintegrasi pada derajat satu (I(1)). Hal ini menunjukkan arah analisa dapat dilakukan baik pada jangka pendek maupun jangka panjang.

\section{Faktor-Faktor Yang Mempengaruhi Neraca Transaksi Berjalan dalam Jangka Panjang}

Dalam penelitian ini uji kointegrasi yang digunakan adalah uji kointegrasi EngleGranger. Setelah lolos uji kointegrasi Engle Granger, maka hasil persamaan regresi jangka Panjang adalah sebagai berikut.

$$
N T B=11478.76-789.5181 \text { interest }-952.5372 \text { inflasi }-0.0049 G D P+2.721 \text { Exchrate }
$$

Adj $R^{2} \quad=0.6262$

$\begin{array}{llll}(0.2374) \quad(0.014) \quad(0.0032) & (0.2987)\end{array}$

Prob. Fstat $=0.0000$ 
Berdasarkan hasil estimasi jangka panjang terdapat dua variabel yang signifikan pada tingkat kepercayaan 5 persen. Variabel tersebut adalah inflasi dengan nilai p value 0.014 dan pendapatan nasional (GDP) dengan nilai p value 0.0032 . Dalam jangka panjang variabel tingkat inflasi memiliki hubungan negatif terhadap neraca transaksi berjalan. Adapun nilai koefisiennya sebesar -952.5372 yang berarti, jika tingkat inflasi naik $1 \%$ maka rata-rata neraca transaksi berjalan akan turun sebesar $\$ 952.5372$ juta.

Variabel lain yang signifikan adalah pendapatan nasional (GDP) dengan nilai koefisien sebesar -0.0049. hal ini berarti, jika pendapatan nasional (GDP) naik Rp 1 triliun, maka rata-rata neraca transaksi berjalan akan turun sebesar $\$ 0.0049$ juta.

Sedangkan variabel tingkat bunga dan nilai tukar pada jangka panjang tidak mempengaruhi neraca transaksi berjalan.

\section{Faktor-Faktor yang Mempengaruhi Neraca Transaksi Berjalan dalam Jangka Pendek}

Dalam penelitian ini uji ekonometrika yang digunakan adalah error correction model. Setelah melakukan pengujian asumsi klasik, yaitu uji normalitas, uji multikolinearitas, uji heteroskedastisitas, dan uji otokorelasi, maka hasil persamaan regresi adalah sebagai berikut.

$$
\begin{aligned}
& d N T B=-807.129-2.94 d \text { Exchrate }-1751.6 \text { dinflasi }+1672.3 \text { dinterest }-0.001 \text { dGDP }-0.689 E C T(-1) \\
& \left.\begin{array}{lllll}
(0.0853) & (0.0277) & (0.2553) & (0.8830) & (0.0329
\end{array}\right) \\
& \text { Adjusted R-squared } \quad=0.4707 \\
& \text { Prob F-stat } \quad=0.080
\end{aligned}
$$

Hasil regresi menunjukkan bahwa nilai koefisien ECT pada model tersebut signifikan dan bertanda negatif untukestimasi Neraca Transaksi Berjalan (NTB). Hasil estimasi ECM di atas memperlihatkan bahwa dalam jangka pendek hanya ada dua variabel yang mempengaruhi neraca transaksi berjalan, yaitu nilai tukar (EXCHRATE) dan tingkat inflasi (INFLASI). Nilai koefisien nilai tukar (EXCHRATE) sebesar -2.94, yang berarti, jika nilai tukar mengalami apresiasi, maka rata-rata neraca transaksi berjalan akan turun sebesar \$2.94 juta pada jangka pendek. Sedangkan nilai koefisien tingkat inflasi (INFLASI) sebesar -1751.6. Hal ini berarti, jika inflasi naik $1 \%$, maka rata-rata neraca transaksi berjalan akan turun sebesar $\$ 1751.6$ juta pada jangka pendek. Akhirnya berdasarkan persamaanjangka pendek tersebut denganmenggunakan metode ECMmenghasilkan koefisien ECT. Koefisien ini mengukur respon regressand setiap periode yang menyimpang dari keseimbangan. Menurut Widarjono (2014) koefisien koreksi ketidakseimbangan ECT dalam bentuk nilai absolut menjelaskan seberapa cepat waktu diperlukan untuk mendapatkan nilai keseimbangan. Nilai koefisien ECTsebesar 0,6894 mempunyai makna bahwa perbedaan antara neraca transaksi berjalan dengan nilai keseimbangannya pada jangka panjang sebesar 0,6894. Error correction term menunjukkan seberapa cepat ekuilibrium tercapai kembali ke keseimbangan jangka panjang. 


\section{Implikasi Managerial}

Pada jangka panjang, tidak semua variabel makroekonomi dalam penelitian ini memiliki pengaruh terhadap neraca transaksi berjalan. Hanya ada dua variabel yang memiliki pengaruh jangka panjang terhadap neraca transaksi berjalan, yaitu pendapatan nasional dan tingkat inflasi. Pada jangka panjang pendapatan nasional berpengaruh negatif signifikan terhadap neraca transaksi berjalan dengan nilai koefisien -0.0049 . hal ini berarti, jika pendapatan nasional (GDP) naik Rp 1 triliun maka rata-rata neraca transaksi berjalan pada jangka panjang akan mengalami defisit sebesar \$0.0049 juta. Hal ini menunjukkan semakin tinggi pendapatan nasional mencerminkan semakin tinggi tingkat kegiatan ekonomi. Tingginya tingkat kegiatan ekonomi menunjukkan tingginya pengeluaran baik yang dilakukan oleh rumah tangga, perusahaan, maupun pemerintah. Hal ini menyebabkan permintaan akan barang impor meningkat untuk memenuhi pengeluaran yang tinggi. Akhirnya neraca transaksi berjalan mengalami defisit. Hasil penelitian ini sejalan dengan penelitian Ukhrowiyah (2014), Hertanti (2007), dan Ramadhani (2015) yang menyatakan bahwa pendapatan nasional (GDP) berpengaruh negatif signifikan terhadap neraca transaksi berjalan.

Variabel lain yang mempengaruhi neraca transaksi berjalan pada jangka panjang adalah tingkat inflasi. Tingkat inflasi memiliki pengaruh negatif signifikan pada jangka panjang terhadap neraca transaksi berjalan dengan nilai koefisien -952.5372 . Hal ini berarti, jika inflasi naik $1 \%$, maka rata-rata neraca transaksi berjalan akan mengalami penurunan sebesar $\$ 952.5372$ juta. Tingginya inflasi menyebabkan daya beli masyarakat menurun sehingga akan menuju kemiskinan. Inflasi merupakan salah satu hal yang sangat dihindari dalam perekonomian terutama inflasi yang tinggi. Hal ini dikerenakan inflasi menyebabkan harga barang domestic menjadi meningkat sehingga tidak kompetitif relatif dibandingkan dengan harga barang pada negara lain. Sehingga menyebabkan permintaan barang dalam negeri menurun yang pada akhirnya menyebabkan neraca transaksi berjalan menjadi defisit. Hasil penelitian ini sejalan dengan penelitian yang dilakukan oleh Calderon (1998) dan Ukhrowiyah (2014) yang menyatakan bahwa tingkat inflasi berpengaruh negatif terhadap neraca transaksi berjalan.

Pada jangka panjang, tingkat bunga dan nilai tukar tidak berpengaruh signifikan terhadap neraca transaksi berjalan. Hal ini dikarenakan pelaku ekonomi dapat mengantisipasi perubahan tingkat bunga dan nilai tukar pada jangka panjang. Pada nilai tukar, pelaku ekonomi dapat melakukan lindung nilai (hedging) untuk kegiatan bisnisnya. Sedangkan pada tingkat bunga, pelaku ekonomi dapat mencari alternatif sumber-sumber pembiayaan apabila tingkat bunga didalam negeri meningkat, yaitu melakukan penerbitan saham maupun obligasi. Nilai koefisien determinasi sebesar 0.6262, yang berarti pada jangka panjang, 62,62 \% variabilitas neraca transaksi berjalan dipengaruhi oleh tingkat bunga, inflasi, pendapatan nasional, dan nilai tukar, sisanya $37,38 \%$ dipengaruhi oleh faktor lain yang diluar model penelitian.

Pada jangka pendek, tidak semua variabel makroekonomi mempengaruhi neraca transaksi berjalan. Hanya variabel nilai tukar dan inflasi yang mempengaruhi neraca transaksi berjalan Indonesia. Pada jangka pendek, nilai tukar berpengaruh negatif 
terhadap neraca transaksi berjalan dengan nilai koefisien - 2.94. hal ini berarti setiap kenaikan rupiah (rupiah terapresiasi) sebanyak Rp.1 maka dalam jangka pendek menyebabkan rata-rata neraca transaksi berjalan akan turun \$2.94 juta. Kenaikan atau menguatnya nilai tukar rupiah (rupiah terapresiasi) menyebabkan harga barang dari Indonesia (barang ekspor) akan menjadi lebih mahal dan harga barang impor menjadi lebih murah. Murahnya harga impor menyebabkan permintaan akan impor meningkat dan sebaliknya permintaan akan ekspor menurun yang pada akhirnya terjadi defisit neraca transaksi berjalan.hal ini berlaku sebaliknya, jika mata uang rupiah mengalami depresiasi, maka harga barang ekspor menurun sedangkan harga barang impor meningkat, yang pada akhirnya permintaan barang ekspor meningkat dan permintaan barang impor menurun. Kondisi ini menyebabkan neraca transaksi berjalan mengalami surplus. Hasil penelitian ini sejalan dengan penelitian yang dilakukan oleh Calderon (1998), Ramadhani (2015), Masdjojo (2005), dan Ukhrowiyah (2014) yang menyatakan bahwa nilai tukar berpengaruh negatif terhadap neraca transaksi berjalan.

Tingkat inflasi juga berpengaruh negatif terhadap neraca transaksi berjalan pada jangka pendek dengan nilai koefisien -1751.599. setiap kenaikan tingkat inflasi sebesar $1 \%$, maka pada jangka pendek rata-rata neraca transaksi berjalan akan turun sebesar \$1751.599 juta. Hal ini berarti inflasi memberikan efek negatif terhadap neraca transaksi berjalan. Jika terjadi inflasi didalam negeri berarti rata-rata tingkat harga produk di dalam negeri mengalami kenaikan. Hal ini menyebabkan permintaan terhadap produk didalam negeri mengalami penurunan atau dengan kata lain ekspor turun dan hal ini mengakibatkan nerca transaksi berjalan mengalami defisit. Hasil penelitian ini sejalan dengan hasil penelitian yang dilakukan oleh Ukhrowiyah (2014) dan Masdjojo (2005) yang menyatakan bahwa tingkat inflasi berpengaruh negatif terhadap neraca transaksi berjalan.

Selain dua variabel tersebut, variabel tingkat bunga dan GDP tidak berpengaruh signifikan pada jangka pendek terhadap neraca transaksi berjalan. Adapun koefisien determinasi pada jangka pendek sebesar 0.471 , yang berarti $47.1 \%$ variabilitas neraca transaksi berjalan dipengaruhi oleh tingkat bunga, inflasi, nilai tukar, dan GDP sisanya $52.9 \%$ dipengaruhi oleh faktor lain diluar model penelitian.

\section{PENUTUP}

Berdasarkan hasil penelitian maka dapat disimpulkan sebagai berikut.

a. Pada jangka panjang, variabel pendapatan nasional (GDP) dan inflasi berpengaruh signifikan terhadap neraca transaksi berjalan. Tingginya inflasi menyebabkan kesejahteraan masyarakat menurun dan berakibat pada kemiskinan. Tingginya harga dalam meneri menyebabkan harga barang ekspor relative menjadi lebih mahal. Hal ini mengakibatkan permintaan barang ekspor menjadi menurn yang berakibat pada neraca transaksi berjalan yang akan mengalami defisit. Pada variabel lain, pendapatan nasional berpengaruh negatif signifikan terhadap neraca transaksi berjalan. Tingginya pendapatan nasional menggambarkan tingginya kegiatan ekonomi. Hal ini berakibat pada tingginya pengeluaran yang dilakukan oleh rumah tangga, perusahaan, dan pemerintah yang berakibat konsumsi rumah 
tangga, perusahaan, dan pemerintah meningkat. Konsumsi yang meningkat ini menyebabkan permintaan barang impor akan meningkat yang pada akhirnya dapat menyebabkan defisit neraca transaksi berjalan.

b. Pada jangka pendek, variabel nilai tukar dan inflasi berpengaruh signifikan terhadap neraca transaksi berjalan. Naiknya nilai tukar (apresiasi) akan berpengaruh defisit neraca transaksi berjalan. Kenaikan atau menguatnya nilai tukar rupiah (rupiah terapresiasi) menyebabkan harga barang dari Indonesia (barang ekspor) akan menjadi lebih mahal dan harga barang impor menjadi lebih murah. Murahnya harga impor menyebabkan permintaan akan impor meningkat dan sebaliknya permintaan akan ekspor menurun yang pada akhirnya terjadi defisit neraca transaksi berjalan.hal ini berlaku sebaliknya, jika mata uang rupiah mengalami depresiasi, maka harga barang ekspor menurun sedangkan harga barang impor meningkat, yang pada akhirnya permintaan barang ekspor meningkat dan permintaan barang impor menurun. Kondisi ini menyebabkan neraca transaksi berjalan mengalami surplus. Selain itu, tingkat inflasi berpengaruh negatif terhadap neraca transaksi berjalan. Hal ini berarti inflasi memberikan efek negatif terhadap neraca transaksi berjalan. Jika terjadi inflasi didalam negeri berarti rata-rata tingkat harga produk didalam negeri mengalami kenaikan. Hal ini menyebabkan permintaan terhadap produk didalam negeri mengalami penurunan atau dengan kata lain ekspor turun dan hal ini mengakibatkan nerca transaksi berjalan mengalami defisit.

c. Adapun variabel makroekonomi yang berpengaruh baik pada jangka panjang maupun jangka pendek adalah tingkat inflasi.

Berdasarkan hasil penelitian maka didapatkan saran sebagai berikut:

a. Pelaku Ekonomi harus Meningkatkan produksi didalam negeri dan berorientasi ekspor yang dapat mempengaruhi kinerja ekonomi Indonesia terutama pada neraca transaksi berjalan serta selalu memperhatikan indikator makroekonomi terutama inflasi yang dapat mempengaruhi kegiatan ekspor dan impor yang tercermin dalam neraca transaksi berjalan baik pada jangka pendek maupun jangka panjang

b. Pemerintah dan Bank Sentral harus menjaga stabilitas makroekonomi dalam menjaga neraca transaksi berjalan terutama dalam menjaga kestabilan harga (inflasi) pada jangka pendek maupun jangka panjang

c. Penelitian Selanjutnya dapat menambah variabel lain selain makroekonomi yang dapat mempengaruhi neraca transaksi berjalan Indonesia atau juga memperluas cakupan penelitian tidak hanya terhadap neraca transaksi berjalan tetapi juga terhadap nerca pembayaran

\section{DAFTAR PUSTAKA}

Cesar Calderon, A. C. (1998). Determinants of Current Account Deficits in Developing Countries. Latin America Regional Studies Program of the World Bank . 
Dornbusch, Rudiger, S. F. (2014). Macroeconomics. McGraw-Hill Education.

Gujarati, D. N. (2008). Basic Econometrics. McGraw-Hill Education .

Mankiw, N. G. (2015). Principles of Economics. Cengage Learning.

Masdjojo, G. N. (n.d.). Analisis Fenomena Moneter Neraca Pembayaran Indonesia:Suatu Studi Tentang Faktor-Faktor yang mempengaruhi Periode 19802003. Tesis Tidak Dipublikasikan. Universitas Diponegoro.

Pappa, M. B. (2013). On The relationship between domestic savings and the current account in poor countries: evidence and theory. Barcelona graduate School Research network.

Ramadhani, M. D. (2015). Analisis faktor-Faktor yang Mempengaruhi Transaksi berjalan Indonesia periode 2006-2013. Jurnal Ekonomi dan Keuangan Vol.2 No.10 , 634-644.

Samuelson, Paul W. N. (2009). Economics. McGraw-Hill Education.

Sobrino R Cesar (2013), The Twin Deficits Hypothesis and Reverse Causality: A Short Run Analysis of Peru, Journal of Economic, Finance, and Administrative Science Vol.18 No.34

Sukirno, Sadono (2016), Makro Ekonomi Teori Pengantar, Edisi 3, Jasakom

Ukhrowiyah, N. (2014). Analisis beberapa faktor yang mempengaruhi defisit neraca transaksi berjalan di Indonesia melalui pendekatan Error Correction Model (ECM). Skripsi Universitas Muhammadiyah Surakarta .

Widarjono, Agus PhD (2014), Ekonometrika Pengantar dan Aplikasinya, UPP STIM YKPN Yogyakarta 